July 2009

\title{
Ventral Intramedullary Cervical Spinal Cord AVM
}

\author{
Sanjay Yadla MD \\ Pascal Jabbour MD \\ Thomas Jefferson University \\ Robert H. Rosenwasser MD \\ Thomas Jefferson University
}

Follow this and additional works at: https://jdc.jefferson.edu/jhnj

\section{Let us know how access to this document benefits you}

\section{Recommended Citation}

Yadla, Sanjay MD; Jabbour, Pascal MD; and Rosenwasser MD, Robert H. (2009) "Ventral Intramedullary Cervical Spinal Cord AVM," JHN Journal: Vol. 4 : Iss. 3 , Article 8.

DOI: https://doi.org/10.29046/JHNJ.004.3.008

Available at: https://jdc.jefferson.edu/jhnj/vol4/iss3/8

This Article is brought to you for free and open access by the Jefferson Digital Commons. The Jefferson Digital Commons is a service of Thomas Jefferson University's Center for Teaching and Learning (CTL). The Commons is a showcase for Jefferson books and journals, peer-reviewed scholarly publications, unique historical collections from the University archives, and teaching tools. The Jefferson Digital Commons allows researchers and interested readers anywhere in the world to learn about and keep up to date with Jefferson scholarship. This article has been accepted for inclusion in JHN Journal by an authorized administrator of the Jefferson Digital Commons. For more information, please contact: JeffersonDigitalCommons@jefferson.edu. 


\section{Ventral Intramedullary Cervical Spinal Cord AVM}

\author{
Sanjay Yadla, MD, Pascal M. Jabbour, MD, Robert H. Rosenwasser, MD, FACS, FAHA \\ Department of Neurological Surgery, Thomas Jefferson University, Philadelphia, PA
}

\section{Abstract}

Spinal Cord Arteriovenous Malformations (SCAVMs) are rare vascular lesions. AVMs of the cervical spinal cord are a small proportion of these. SCAVMs are generally classified into four categories based on location and structure. They may cause significant neurologic symptoms by direct mass effect or venous congestion. Surgery of these lesions may be associated with considerable morbidity and thus a multimodality approach using endovascular and radiosurgery techniques is required.

Spinal Cord AVMs are rare lesions, only one-tenth as common as their cranial counterparts ${ }^{1}$. They may clinically present with progressive symptoms from direct mass effect or venous hypertension or acutely after hemorrhage. In 1992, Anson and Spetzler, published the most widely used classification of SCAVMs (Table 1$)^{2}$.

Type II or Glomus AVMs typically have multiple arterial feeders and drain into a venous plexus around the spinal cord. They can be particularly difficult to treat because they are intramedullary, within the spinal cord parenchyma. The mortality rate related to Type II AVMs has been reported as close to $18 \%$. After initial hemorrhage, the rebleed rate is 10\% within the first month and $40 \%$ within the first year ${ }^{3}$.

We present the case of a 42 -year-old woman who initially presented with calf pain who was found to have a ventral cervical intramedullary AVM.

\section{Case Report}

History. This 42-year-old woman initially presented to her primary care physician several months before admission with calf pain and left foot numbness. She was eventually referred to a rheumatologist who diagnosed her with a connective tissue disorder. The calf pain continued with new symptoms of bilateral hand paresthesias. She returned to her primary care physician who ordered MRIs of the lumbar and cervical spine. The cervical spine MRI revealed an arteriovenous malformation at the C2 with an intramedullary nidus. She was then referred to our department.

Examination. At admission, the woman had mild bilateral triceps weakness and proximal right lower extremity weakness. Sensation was decreased in all modalities in a stocking distribution in the left leg. Reflexes were hyperreactive in the right lower extremity and decreased in the left. No Babinski's or Hoffman's sign was elicited and rectal exam was normal.

Table 1: Common Classification of Spinal Cord AVMs (2).

\begin{tabular}{|c|c|c|c|c|}
\hline & Location in Spinal Cord & Location of vessels & Commonly Affected Population & Flow Dynamicss \\
\hline Type I, Dural AV Fistula & $\begin{array}{l}\text { Dorsal Lower Thoracic } \\
\text { Spine or Conus }\end{array}$ & $\begin{array}{l}\text { Transdural, } \\
\text { single arterial feeder }\end{array}$ & $\begin{array}{l}\text { Male predominance, } \\
\text { between } 5 \text { th and } 8 \text { th decades }\end{array}$ & $\begin{array}{l}\text { Low Pressure, } \\
\text { High Flow }\end{array}$ \\
\hline Type II, Glomus & Dorsal Cervicomedullary & Intramedullary & Younger population & $\begin{array}{l}\text { Low Pressure, } \\
\text { High Flow }\end{array}$ \\
\hline Type III, Juvenile & & $\begin{array}{l}\text { Intramedullary } \\
\text { extramedullary, multiple }\end{array}$ & $\begin{array}{l}\text { Young adults, children } \\
\text { extraspinal feeders }\end{array}$ & $\begin{array}{l}\text { Low Pressure, } \\
\text { High Flow }\end{array}$ \\
\hline Type IV & Anterior to spinal cord & $\begin{array}{l}\text { Intradural and } \\
\text { Extramedullary, perimedullary, } \\
\text { fed by Anterior Spinal Artery }\end{array}$ & Between 3rd and 6th decade & $\begin{array}{l}\text { Low Pressure, } \\
\text { High Flow }\end{array}$ \\
\hline
\end{tabular}

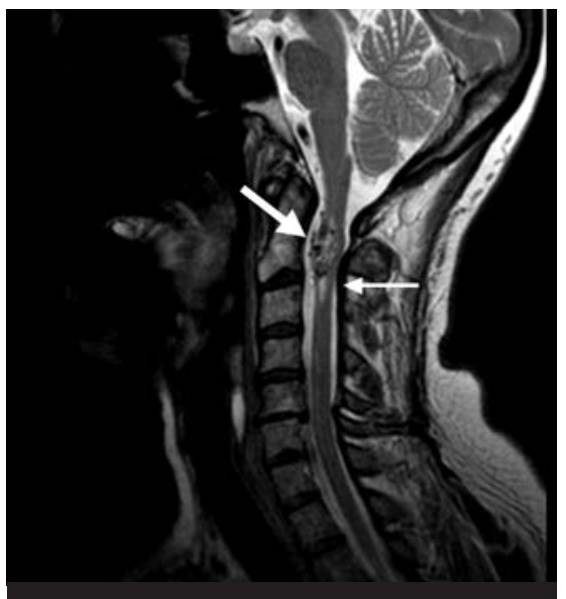

\section{Figure 1}

Sagittal T2-Weighted MR Imaging of the cervical spine showing signal voids consistent with an intramedullary AVM (large white arrow) and signal within the spinal cord suggesting venous congestion or edema (small white arrow).

Neuromaging Studies. MRI of the cervical spine revealed a $1.3 \times 2.5$ centimeter lesion with internal flow voids and associated signal within the adjacent cord (Figures 1,2). Transfemoral spinal angiogram was performed to clarify the angioarchitecture of the lesion and its feeding vessels (Figure 3). Two arterial feeders were found arising from the right vertebral artery.

Pharmacologic Provocative Testing. In order to determine the eloquence of the territory supplied by the feeding arteries we performed 


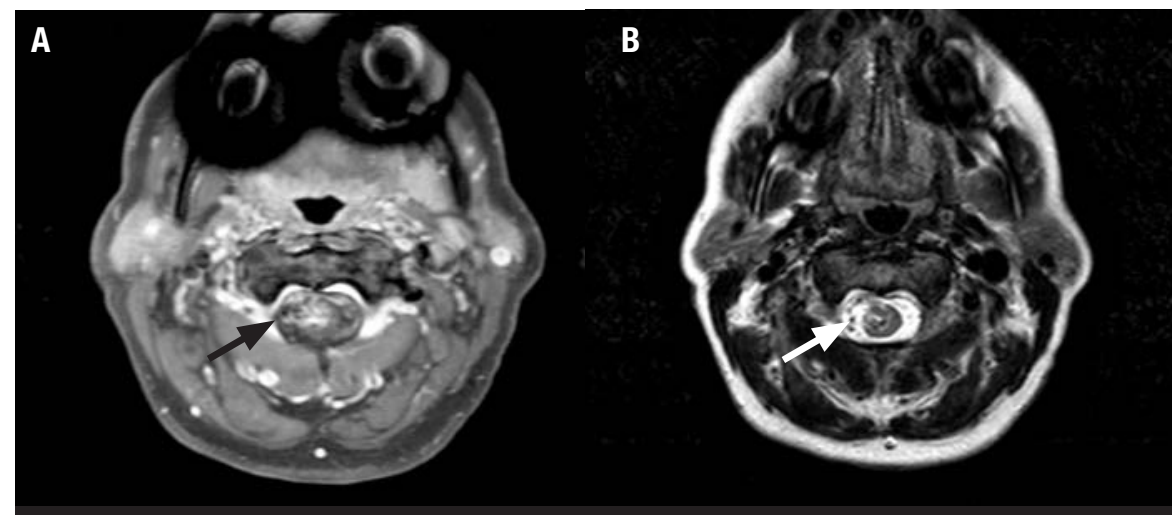

Figure 2

T1 Post-Contrast (A) and T2 Weighted (B) Imaging of the affected level showing enhancement and flow voids consistent with an intramedullary arteriovenous malformation.

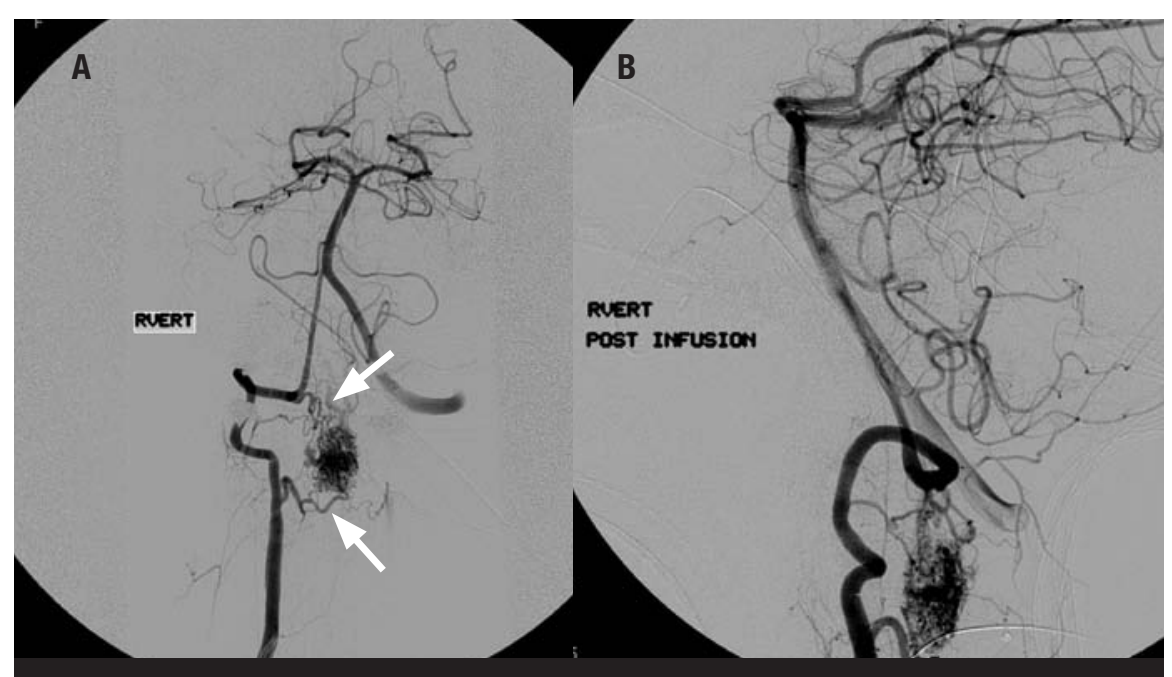

Figure 3

Transfemoral angiogram. Anterior-posterior (A) and Lateral (B) views of a right vertebral injection revealing two feeding pedicles off of the right vertebral artery (white arrows).

provocative testing using short-acting anesthestetics via a microcatheter placed in the superior feeding vessel ${ }^{4}$. The patient was under general anesthesia during the procedure to obtain better imaging and for the patient's comfort. Recording electrodes were placed on all extremities and both motor evoked potentials (MEPs) and somatosensory evoked potentials (SSEPs) were recorded throughout the procedure.

The superior feeding pedicle was first catheterized using a microcatheter (Figure 4). First, one hundred milligrams of sodium amytal was injected into the feeding vessel to simulate what the permanent response would be to a liquid embolic agent. MEPs and SSEPs remained normal after the injection. Next, fifty milligrams of lidocaine was injected. Upper and lower extremity MEPs on the right and lower extremity MEPs on the left decreased by greater than $50 \%$. After thirty minutes the MEPs returned to normal. It was then decided that the risk of proceeding with embolization given that signals changed with provocative testing was too high. The procedure was halted and the patient was awoken.

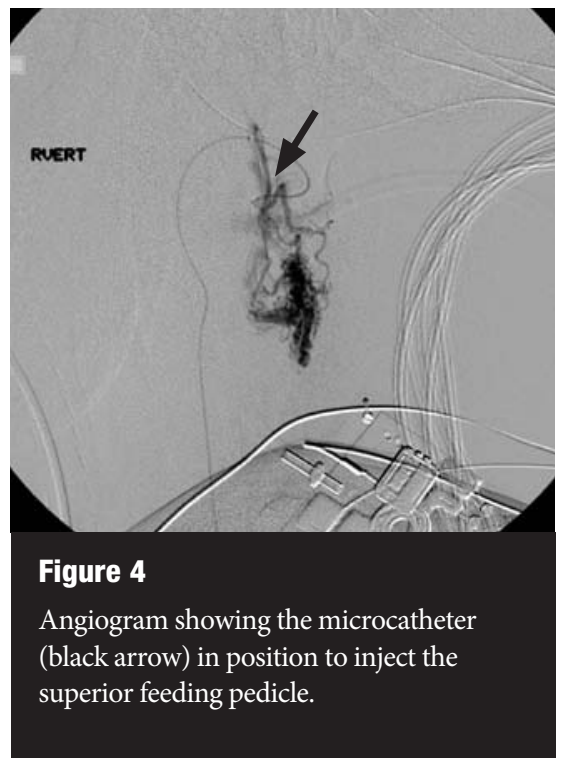

\section{Discussion}

Cervical spinal arteriovenous malformations may present significant challenges to the clinician. Location proximal to or within critical structures may prohibit the normal application of surgical, radiosurgical, or endovascular tools. The dynamic nature of feeding and draining vessels makes it extremely important to delineate which vessels supply eloquent regions and which do not.

The current patient illustrates the difficulty in management of these patients. The location of the lesion in the ventral cervical spinal cord makes surgical intervention exceedingly difficult. Provocative pharmacologic testing suggested that the deployment of liquid embolic agents into feeding pedicles might be neurologically devastating to the patient. Radiosurgery targeted to the nidus may lead to the same impairments if the vascular supply to eloquent areas of the cord was affected. The complicated treatment of intramedullary SCAVMs may reflect the poor outcomes associated with them in the literature.

\section{References}

1. Veznedaroglu E, Nelson PK, Jabbour PM, Rosenwasser RH: Endovascular Treatment of Spinal Cord Arteriovenous Malformations. Neurosurgery 59:S3-202-209, 2006.

2. Anson JA, Spetzler RF. Interventional Neuroradiology for Spinal Pathology. Clinical Neurosurgery 39:388-417, 1992.

3. Aminoff MJ, Logue V: The Prognosis of Patients with Spinal Vascular Malformations. Brain 97:211-218, 1974

4. Niimi Y, Sala F, Deletis V, Setton A, Bueno de Camargo A, Berenstein A: Neurophysiologic Monitoring and Pharmacologic Provocative Testing for Embolization of Spinal Cord Arteriovenous Malformations. AJNR 25: 11311138, 2004. 